\title{
Milk performance and glucose metabolism in dairy cows fed rumen-protected fat during mid lactation
}

\author{
A.-K. Lohrenz, ${ }^{\star}$ K. Duske, ${ }^{*}$ F. Schneider, ${ }^{*}$ K. Nürnberg, ${ }^{*}$ B. Losand,† H. M. Seyfert, ${ }^{*}$ C. C. Metges, ${ }^{\star}$ \\ and H. M. Hammon*1 \\ *Leibniz Institute for Farm Animal Biology (FBN), 18196 Dummerstorf, Germany \\ †State Institute of Animal Production, 18196 Dummerstorf, Germany
}

\begin{abstract}
Feeding rumen-protected fat (RPF) can improve energy supply for dairy cows but it affects glucose metabolism. Glucose availability is a precondition for high milk production in dairy cows. Therefore, this study investigated endocrine regulation of glucose homeostasis and hepatic gene expression related to glucose production because of RPF feeding in lactating cows. Eighteen Holstein dairy cows during second lactation were fed either a diet containing RPF (mainly C16:0 and C18:1; FD; $\mathrm{n}=9$ ) or a control diet based on corn starch (SD; $\mathrm{n}=9$ ) for $4 \mathrm{wk}$ starting at $98 \mathrm{~d}$ in milk (DIM). Feed intake and milk yield were measured daily and milk composition once a week. Blood samples were taken weekly for analyses of plasma triglyceride, nonesterified fatty acids (NEFA), $\beta$-hydroxybutyrate, bilirubin, urea, lactate, glucose, insulin, and glucagon. At 124 DIM, an intravenous glucose tolerance test (GTT; $1 \mathrm{~g} / \mathrm{kg}$ of $\mathrm{BW}^{0.75}$ ) was performed after a 12 -h period without food. Blood samples were taken before and 7, 14, 21, and 28 min after glucose administration, and plasma concentrations of glucose, insulin, and glucagon were measured. Glucose half-life as well as areas under the concentration curve for glucose, insulin, and glucagon were calculated. After slaughter at d 28 of treatment, liver samples were taken to measure mRNA abundance of pyruvate carboxylase, cytosolic phosphoenolpyruvate carboxykinase, glucose 6-phosphatase (G6Pase), and facilitative glucose transporter 2. Dry matter intake, but not energy and protein intake, was lower in FD than in SD. Milk yield during lactation decreased more in SD than in FD, and milk protein was lower in FD than in SD. Plasma concentrations of triglycerides and NEFA were higher in FD than in SD. Plasma insulin concentrations were lower and the glucagon:insulin ratios were higher in FD than in SD. Fasting glucose concentration before GTT was lower, and fasting glucagon
\end{abstract}

Received April 15, 2010.

Accepted September 6, 2010.

${ }^{1}$ Corresponding author: hammon@fbn-dummerstorf.de concentrations tended to be higher in FD than in SD. In liver, fat content tended to be higher and G6Pase mRNA abundance was lower in FD than in SD. Lower hepatic G6Pase mRNA abundance was associated with reduced fasting plasma glucose concentrations, but the glucose-induced insulin response was not affected by RPF feeding. Hepatic G6Pase gene expression might be affected by DMI and might be involved in the regulation of glucose homeostasis in dairy cows, resulting in a lower hepatic glucose output after RPF feeding.

Key words: dairy cow, glucose metabolism, rumenprotected fat

\section{INTRODUCTION}

Feeding rumen-protected fat (RPF) is a strategy widely used to enhance energy density of the ration and consequently increase energy supply to dairy cows without negative effects on rumen fermentation (Palmquist and Jenkins, 1980; Emery and Herdt, 1991; Grummer and Carroll, 1991). Milk production is variably affected by RPF feeding depending on fat source, diet components, and lactation stage (Onetti and Grummer, 2004). When isoenergetic diets based on starch were compared with diets including RPF, elevated milk yield after RPF feeding was associated with higher lactose output, although less glycogenic precursors were fed or DMI was reduced after RPF feeding (van Knegsel et al., 2005; Voigt et al., 2005; Hammon et al., 2008). As mammary glucose supply is important for adequate milk production (Linzell, 1972; Brockman, 2005), obviously a glucose-sparing effect occurs with RPF feeding and dairy cows use less glucose for oxidation and milk fat synthesis, with the result that more glucose is available for lactose synthesis in the mammary gland (Grummer and Carroll, 1991; Voigt et al., 2005). Furthermore, plasma glucose concentrations were reduced by RPF feeding or infusion of long-chain fatty acids into the abomasum (Benson et al., 2002; Voigt et al., 2005; Hammon et al., 2008).

In ruminants, glucose mainly originates from gluconeogenesis $(85 \%$ from the liver and the remainder 
from the kidney) with very limited net portal absorption (Benson et al., 2002; Brockman, 2005). Therefore, glucose production in the liver is critical for glucose supply in dairy cows, but effects of long-chain fatty acids on hepatic glucose production are inconsistent. Feeding RPF (Ca soaps mainly consisting of C16:0 and C18:1 fatty acids) reduced DMI, but did not affect glucose turnover in dairy cows, although plasma glucose concentrations were decreased (Hammon et al., 2008). However, vegetable oil infused in the abomasum reduced hepatic glucose output in dairy cows (Benson et al., 2002). Plasma glucose concentrations may also be affected by glucose clearance rate and therefore depend on milk production and insulin action (Bauman, 2000; Vernon, 2005a). Gluconeogenic activity in liver is reflected by changes in gene expression of gluconeogenic enzymes (Greenfield et al., 2000; Brockman, 2005), but effects of RPF feeding on changes in hepatic enzymes related to endogenous glucose production are not known.

The objective of this study was to investigate glucose metabolism with a focus on glucose-dependent insulin release and hepatic glucose metabolism. We have tested the hypotheses that RPF feeding affects hepatic gene expression of gluconeogenic enzymes and glucosedependent insulin and glucagon secretion in dairy cows when compared with a starch-based control diet in mid lactation.

\section{MATERIALS AND METHODS}

\section{Animals, Husbandry, and Feeding}

The experimental protocol was approved by the relevant authorities (Landesamt für Landwirtschaft, Lebensmittelsicherheit und Fischerei MecklenburgVorpommern; LALLF M-V/TSD/7221.3-1.1-048/05; LALLF M-V/TSD/7221.3-1.2-008/06). Eighteen German Holstein cows, half-sisters (same bull as father) with comparable milk production (first lactation $>9,000$ $\mathrm{kg}$ milk in $305 \mathrm{~d}$ ), were used during second lactation. Before starting this study, cows were involved in a study with different dietary treatment during late gestation and the dry period ( $12 \mathrm{wk}$ before parturition), but with the same lactation diet after parturition up to 98 DIM (Duske et al., 2009). From wk 15 to 18 in lactation, cows were fed TMR based on corn starch (SD) or containing RPF (FD). For logistic reasons, 3 cows in the SD group and 3 cows of the FD group were investigated during the same period (block), respectively. Ingredients and chemical composition of the different diets are shown in Table 1. Diets were formulated so that the added fat replaced starch. Allocation of cows to feeding groups ( $\mathrm{n}=9$ /group) corresponded to the respective feeding
Table 1. Ingredients and chemical composition of starch-based diet (SD) and diet with rumen-protected fat (FD)

\begin{tabular}{|c|c|c|}
\hline \multirow[b]{2}{*}{ Item } & \multicolumn{2}{|c|}{ Group } \\
\hline & $\mathrm{SD}$ & FD \\
\hline \multicolumn{3}{|l|}{ Ingredient, $\mathrm{g} / \mathrm{kg}$ of $\mathrm{DM}$} \\
\hline Corn silage & 272 & 290 \\
\hline Grass silage & 250 & 277 \\
\hline Hay & 32 & 34 \\
\hline Dried pulp & 106 & 155 \\
\hline Corn starch & 127 & - \\
\hline Rumen-protected fat ${ }^{1}$ & - & 57 \\
\hline Soybean meal & 95 & 67 \\
\hline Protected soybean $^{2}$ & 49 & 52 \\
\hline Barley meal & 48 & 51 \\
\hline Urea & 3 & 4 \\
\hline Minerals/vitamins & 13 & 13 \\
\hline Limestone & 5 & - \\
\hline \multicolumn{3}{|c|}{ Chemical analyses, per $\mathrm{kg}$ of DM } \\
\hline $\mathrm{CP}, \mathrm{g}$ & 170 & 185 \\
\hline Utilizable protein, ${ }^{3} \mathrm{~g}$ & 162 & 169 \\
\hline Crude fiber, $g$ & 163 & 182 \\
\hline Starch, g & 240 & 120 \\
\hline Crude fat, $g$ & 22 & 60 \\
\hline $\mathrm{NE}_{\mathrm{L}},{ }^{3} \mathrm{MJ}$ & 7.04 & 7.56 \\
\hline
\end{tabular}

${ }^{1}$ Hajenol (Harles und Jentzsch GmbH, Uetersen, Germany) contained $840 \mathrm{~g} / \mathrm{kg}$ DM of crude fat (1.5\% myristic acid, $44 \%$ palmitic acid, $5 \%$ stearic acid, $40 \%$ oleic acid, and $9.5 \%$ linoleic acid), $20.2 \mathrm{MJ}$ of $\mathrm{NE}_{\mathrm{L}} / \mathrm{kg}$ of DM, $120 \mathrm{~g} / \mathrm{kg} \mathrm{DM}$ of crude ash, and $95 \mathrm{~g} / \mathrm{kg} \mathrm{DM}$ of calcium.

${ }^{2}$ Byoprofin (Wulfa-Mast GmbH, Dinklage, Germany); protection of extracted soybean meal was through formaldehyde treatment.

${ }^{3}$ German Society of Nutrition Physiology (2001).

during the dry period (Duske et al., 2009). Cows of SD and FD groups did not differ with regard to BW and back fat thickness (Duske et al., 2009) at begin of the experiment.

The rumen-protected fat (Hajenol, Harles und Jentzsch GmbH, Uetersen, Germany) used consisted of Ca salts with mainly palmitic and oleic acids (Duske et al., 2009), and its apparent digestibility was $78.3 \%$ (Voigt et al., 2006). Diets were fed ad libitum at 0600 and 1500 $\mathrm{h}$. The cows were milked twice daily at 0500 and 1600 $\mathrm{h}$, and were housed in a freestall barn with individual troughs placed on scales (Bayerische Landesanstalt für Landwirtschaft, Institut für Landtechnik, Bauwesen und Umwelttechnik, Freising, Germany) to monitor individual feed intake. Cows had free access to water.

\section{Analyses in Feed and Milk}

Dry matter, crude fat, and crude fiber of freeze-dried dietary components and TMR were determined according to the Weender standard procedure (Naumann and Bassler, 1993). Nitrogen was determined by combustion analysis (CNS-2000, Leco Corp., St. Joseph, MI), and $\mathrm{CP}$ was then calculated by multiplying the $\mathrm{N}$ content by 6.25 . The utilizable protein and $\mathrm{NE}_{\mathrm{L}}$ in the diets 
were calculated according to German Society of Nutrition Physiology (2001).

Milk aliquots were collected once weekly during morning milking for determination of fat, protein, and lactose contents. Determination of milk fat, protein, and lactose in milk was performed by the Landeskontrollverband für Leistungs- und Qualitätsprüfung Mecklenburg-Vorpommern e.V. (Güstrow, Germany) using an infrared spectrophotometric method (Milkoscan, Foss Germany, Rellingen, Germany). Yield of ECM was calculated as follows: $\mathrm{ECM}(\mathrm{kg})=[(0.38 \times \mathrm{g}$ of crude fat $+0.24 \times \mathrm{g}$ of $\mathrm{CP} \times 0.17 \mathrm{~g}$ of lactose) $\times \mathrm{kg}$ of milk] $/ 3.14$ (Reist et al., 2003). Milk fatty acid composition was determined in milk samples at the end of the 4-wk experiment as previously reported (Duske et al., 2009).

Energy balance (EB) of cows was calculated as follows: $\mathrm{EB}=\mathrm{EI}\left(\mathrm{MJ}\right.$ of $\left.\mathrm{NE}_{\mathrm{L}} / \mathrm{d}\right)-$ [maintenance energy requirement (MJ of $\mathrm{NE}_{\mathrm{L}} / \mathrm{d}$ ) + milk energy ( $\mathrm{MJ}$ of $\mathrm{NE}_{\mathrm{L}} / \mathrm{d}$ )], where energy intake (EI) was calculated as $\mathrm{NE}_{\mathrm{L}}$ (German Society of Nutrition Physiology, 2001), maintenance energy $\left(\mathrm{MJ}\right.$ of $\mathrm{NE}_{\mathrm{L}} / \mathrm{d}$ ) was calculated as $0.293 \times \mathrm{BW}^{0.75}$, and milk energy $\left(\mathrm{MJ}\right.$ of $\left.\mathrm{NE}_{\mathrm{L}} / \mathrm{d}\right)=$ milk $(\mathrm{kg} / \mathrm{d}) \times[0.95+0.38 \times$ fat $\%+0.21 \times$ protein \% $]$ (German Society of Nutrition Physiology, 2001).

\section{Blood and Rumen Fluid Sampling and Analyses}

Jugular vein blood samples were taken $5 \mathrm{~d}$ before and on $\mathrm{d} 1,7,14,21$, and $28 \mathrm{~d}$ of the experimental feeding period at $0900 \mathrm{~h}$, respectively. Blood was collected in vacutainers (Vacuette, Greiner bio-one, Kremsmünster, Austria) containing EDTA for determination of triglycerides, NEFA, BHBA, lactate, glucose, urea, bilirubin, insulin and glucagon. In addition, an intravenous glucose tolerance test (GTT) was performed 2 to $3 \mathrm{~h}$ after morning milking on $\mathrm{d} 26$ of the study. Cows received jugular cannulas for blood sampling and, after a period of $12 \mathrm{~h}$ without food, glucose $\left(1 \mathrm{~g} / \mathrm{kg}^{0.75} \mathrm{BW}\right)$ was infused into the jugular vein (Hammon et al., 2007). Blood samples were collected before and 7, 14, 21, and 28 min after glucose infusion in tubes containing dipotassium-EDTA (1.8 g/L blood, Monovette, Sarstedt, Nümbrecht, Germany) for determination of glucose, insulin, and glucagon. Blood samples were stored on ice directly after withdrawal and were centrifuged 30 min later. All samples were centrifuged at $4^{\circ} \mathrm{C}$ at 1,500 $\times g$ for $20 \mathrm{~min}$. Aliquots were stored at $-20^{\circ} \mathrm{C}$ until analysis.

Plasma metabolites (triglycerides, NEFA, BHBA, lactate, glucose, urea, and bilirubin) were analyzed by the Landesamt für Landwirtschaft, Lebensmittelsicherheit und Fischerei Mecklenburg-Vorpommern (Rostock, Germany) using routine methods. Analyses were performed using commercially available kits (NEFA: cat. no. FA115; BHBA: cat. no. RA-RB1007; bilirubin: cat. no. BR411, all from Randox, Crumlin, UK; glucose: cat. no. GOP-PAP, LT-GL 0103; triglycerides: cat. no. GPO-PAP LT-TR 0015; urea cat. no. LT-UR0010; lactate cat. no. LT-LC 0013, all from Labor + Technik Lehmann, Berlin, Germany). All measurements were carried out by using an automatic spectrophotometer (Cobas Mira, Roche, Basel, Switzerland).

Insulin was measured in plasma by RIA using a porcine kit (PI-12K, Linco Research, St. Charles, MO; Hammon et al., 2009). A standard curve was prepared at concentrations from 2 to $200 \mu \mathrm{U} / \mathrm{mL}$. Cross-reactivity with bovine insulin was $90 \%$. Previous findings have shown that this assay exhibited good linearity for the range of 25 to $100 \mu \mathrm{U} / \mathrm{mL}$ concentrations in bovine plasma samples. The sensitivity of the insulin RIA (the lowest detectable level) of this insulin RIA method was $2 \mu \mathrm{U} / \mathrm{mL}$. Intra- and interassay $\mathrm{CV}$ were 8.2 and $4.3 \%$, respectively. Glucagon was measured by RIA using a kit from Linco (GL-32K, Linco Research; Hammon and Blum, 1998). Intra- and interassay CV were 9.6 and $5.8 \%$, respectively. The assay is specific for the determination of pancreatic glucagon in serum or plasma in most mammals. Cross-reactivity to oxyntomodulin, which is the primary gut glucagon, was less than $0.1 \%$.

Rumen liquid was taken on d 25 of the experiment $4 \mathrm{~h}$ after morning milking using a ruminal probe. Concentrations of rumen VFA were measured as described by Shen et al. (2004).

\section{Liver Sampling and Analyses}

Cows were slaughtered at the end of the feeding experiment, and liver samples of the right lobe (about 5 g) were taken for analysis of glycogen and fat content as well as mRNA levels of cytosolic phosphoenolpyruvate carboxykinase (PEPCK; EC 4.1.1.32), pyruvate carboxylase (PC; EC 6.4.1.1), glucose-6-phosphatase (G6Pase; EC 3.1.3.9), and glucose transporter (GLUT2). Samples were frozen in liquid nitrogen and stored at $-80^{\circ} \mathrm{C}$ until analyzed. Freeze-dried liver samples were ground in liquid nitrogen immediately before analysis. Liver glycogen was determined using a commercial photometric test kit based on amyloglucosidase-catalyzed release of glucose (no. 207748, Boehringer Mannheim, Mannheim, Germany). Determination of liver fat content was done based on carbon and nitrogen content, as described by Duske et al. (2009).

For mRNA measurements, total RNA was extracted using TRIzol Reagent (Invitrogen, Karlsruhe, Germany) and resuspended in RNase-free water. The integrity and purity of RNA were tested by measurement of optical density (ratios at 260 and $280 \mathrm{~nm}$ being 
greater than 1.9) and by electrophoresis using ethidium bromide staining. Total RNA was reverse transcribed into cDNA using random primers (Random Primers, Invitrogen, Karlsruhe, Germany) as described (Hammon et al., 2009).

Real-time, reverse transcription (RT)-PCR was performed by LightCycler (Roche Molecular Biochemicals, Mannheim, Germany) using SYBR Green I as fluorescence dye (Hammon et al., 2009). Primers used for PCR measurement of PEPCK, PC, G6Pase, and GLUT2 were published recently (Hammon et al., 2009). Primers were designed to flank a region that contains at least one intron to ensure that no contaminating genomic DNA was amplified that could lead to false signals. Quantification of mRNA was performed by relative expression using $\beta$-actin (forward primer: ATCACCATCGGCAATGAGC; reverse primer: TGATCCACATCTGCTGGAAG) as reference gene transcript (Pfaffl, 2001; Hammon et al., 2009). Inter- and intraassay CV for RT-PCR of target and reference genes were below $1 \%$, respectively.

\section{Statistical Analyses}

Statistical analyses were done with the SAS System for Windows, release 9.1.3 (SAS Institute Inc., 2004). Data are given as LSM \pm pooled SEM. Area under the curve (AUC) and glucose half-life during GTT were calculated as described recently (Hammon et al., 2007). Milk performance, DMI, and plasma concentrations of metabolites and hormones during the 4-wk feeding study were assessed by repeated measurements ANOVA using the MIXED procedure. The ANOVA model used contained the fixed effects diet (SD, FD), time of blood sampling (d -5, 1, 7, 14, 21, and 28), block (1, 2, 3; period of investigation), and the interactions between diet, time, and block during the 4-wk experiment, and a random cow effect using the combination of autoregressive structure within animals and a random effect between animals as covariate structure (Littell et al., 1998). Additionally, all pairwise differences of these LSM were tested using the Tukey-Kramer procedure. Differences with $P<0.1$ were considered as trends and with $P<0.05$ as significant. Because milk yield was higher in SD than in FD before the start of the experiment (Duske et al., 2009), milk yield at 98 DIM was included as covariable into the model when calculating milk performance data. Differences for glucose, insulin, and glucagon measurements during GTT, milk fatty acids, VFA composition in the rumen, and hepatic parameters were analyzed by GLM with diet, block, and diet $\times$ block interaction as fixed effects. Differences with $P<0.1$ were considered as trends and with $P<$ 0.05 as significant. The CORR procedure was used to calculate and test Pearson correlations between hepatic measurements and plasma concentrations of metabolites and hormones. Linear regression was calculated by Microsoft Excel, 2007 (Microsoft Corp., Redmond, WA).

\section{RESULTS}

\section{Feed Intake, Milk Production and Composition, and Energy Balance}

Slight increases $(P<0.1)$ of DMI and energy intake were observed during the 4 -wk experimental period in both groups, and DMI, but not energy intake, was higher $(P<0.01)$ in SD than in FD (Table 2). Intakes of crude and utilizable protein tended to increase $(P<$ 0.1 ) with time in both groups, and utilizable protein intake tended to be higher $(P<0.1)$ in SD than FD. A trend was also observed for increasing starch and fat intake with time $(P<0.1)$ and, as targeted, starch intake was higher $(P<0.001)$ in SD, whereas fat intake was higher $(P<0.001)$ in FD. Milk yield during the 4 -wk experiment was not affected by diet and did not change with time, but milk yield tended to decrease more $(P<0.1)$ in SD than in FD compared with preexperimental milk yield at 98 DIM (the decrease was -3.9 and $-2.1 \pm 0.7 \mathrm{~kg}$ for SD and FD, respectively). Milk fat and lactose did not change with time or diet, but ECM decreased slightly $(P<0.05)$ with time, and milk protein content and yield decreased mainly in FD, resulting in lower milk protein content $(P<0.01)$ and yield $(P<0.05)$ in FD than SD. Because of increasing DMI and energy intake, EB tended to increase $(P<$ 0.1 ) during the 4 -wk experiment, but showed no differences with regard to feeding.

At the end of the experiment, composition of milk fatty acids was significantly affected by RPF feeding (data not shown). Medium-chain fatty acids and total saturated fatty acids were higher $(P<0.01)$ in SD than in FD (C12:0: 4.9 and $3.1 \pm 0.2 \%$ for $\mathrm{SD}$ and $\mathrm{FD}$, respectively; C14:0: 13.7 and $10.6 \pm 0.4 \%$ for $\mathrm{SD}$ and FD, respectively; saturated fatty acids: 76.2 and 68.5 $\pm 1.1 \%$ for SD and FD, respectively), whereas polyunsaturated fatty acids (PUFA) and especially n-6 fatty acids were higher $(P<0.01)$ in FD than in SD (PUFA: 3.1 and $4 \pm 0.1 \%$ for SD and FD, respectively; n-6: 1.9 and $2.5 \pm 0.1 \%$ for SD and FD, respectively).

\section{Metabolic and Endocrine Changes, GTT, and Rumen VFA}

Plasma triglyceride concentrations were higher $(P<$ $0.001)$ and NEFA concentrations tended to be higher $(P<0.1)$ in FD than in SD (Table 3). Triglyceride 
Table 2. Intake of DM, energy $\left(\mathrm{NE}_{\mathrm{L}}\right)$, protein, starch, and fat as well as milk yield and composition, and energy balance in cows fed starch (SD) and rumen-protected fat (FD) diet for 4 wk between 98 and 124 DIM

\begin{tabular}{|c|c|c|c|c|c|c|}
\hline \multirow[b]{2}{*}{ Variable $^{1}$} & \multicolumn{2}{|c|}{ Group } & \multirow[b]{2}{*}{$\mathrm{SE}$} & \multicolumn{3}{|c|}{ ANOVA ( $P$-value $)$} \\
\hline & $\mathrm{SD}$ & FD & & Diet & Time & Diet $\times$ Time \\
\hline $\mathrm{CP}, \mathrm{kg} / \mathrm{d}$ & 3.5 & 3.41 & 0.08 & 0.5 & 0.1 & 0.8 \\
\hline Utilizable protein, ${ }^{2} \mathrm{~kg} / \mathrm{d}$ & 3.33 & 3.11 & 0.08 & 0.1 & 0.1 & 0.8 \\
\hline Starch, $\mathrm{kg} / \mathrm{d}$ & 4.94 & 2.21 & 0.09 & 0.001 & 0.1 & 0.7 \\
\hline Crude fat, $\mathrm{kg} / \mathrm{d}$ & 0.45 & 1.1 & 0.02 & 0.001 & 0.1 & 0.6 \\
\hline $\mathrm{ECM}, \mathrm{kg} / \mathrm{d}$ & 33.1 & 32.8 & 1.1 & 0.9 & 0.05 & 0.6 \\
\hline Milk fat, $\%$ & 4.78 & 4.72 & 0.2 & 0.8 & 0.15 & 0.8 \\
\hline Milk fat, $\mathrm{kg} / \mathrm{d}$ & 1.34 & 1.41 & 0.06 & 0.4 & 0.8 & 0.7 \\
\hline Milk protein, $\%$ & 3.34 & 2.97 & 0.05 & 0.01 & 0.05 & 0.01 \\
\hline Milk protein, $\mathrm{kg} / \mathrm{d}$ & 1.03 & 0.94 & 0.03 & 0.05 & 0.1 & 0.8 \\
\hline Lactose, $\%$ & 4.71 & 4.7 & 0.03 & 0.8 & 0.3 & 0.3 \\
\hline Lactose, $\mathrm{kg} / \mathrm{d}$ & 1.47 & 1.49 & 0.03 & 0.6 & 0.3 & 0.2 \\
\hline
\end{tabular}

${ }^{1}$ Values are LSM with pooled SE.

${ }^{2}$ German Society of Nutrition Physiology (2001).

concentrations mainly increased in FD during the first week of RPF feeding. Time-related changes concerning plasma concentrations of BHBA $(P<0.05)$, urea $(P$ $<0.01)$, and bilirubin $(P<0.1)$ were also noted, but no differences were found with respect to diet. Plasma insulin concentrations were higher $(P<0.05)$ during the experimental period in SD than in FD, but plasma glucagon concentrations tended to be lower $(P=0.1)$ and the glucagon to insulin ratio was lower $(P<0.01)$ in SD than in FD (Figure 1). A negative correlation was found between plasma NEFA and insulin concentrations $(\mathrm{r}=-0.55 ; P<0.05)$, but a positive correlation was found between plasma NEFA and the glucagon to insulin ratio in plasma $(\mathrm{r}=0.78 ; P<0.001)$.

Before glucose infusion during GTT, fasting plasma glucose concentrations were lower $(P<0.05)$ and fasting plasma glucagon concentrations tended to be higher $(P<0.1)$ in FD than in SD (Table 4). After glucose infusion, plasma glucose and insulin concentrations increased and plasma glucagon concentrations decreased. The plasma glucose increase after glucose infusion tended to be higher $(P<0.1)$ in FD than in SD, and the glucose increase was also affected by block $(P<$ $0.05)$. Fasting plasma concentrations of glucose and insulin were positively related $(\mathrm{r}=0.49 ; P<0.05)$.

Rumen fluid contained $99.1 \pm 5.8 \mathrm{mmol} / \mathrm{L}$ VFA including $62.3 \pm 1.2 \mathrm{~mol} / 100 \mathrm{~mol}$ acetate, $19.7 \pm 0.7$ $\mathrm{mol} / 100 \mathrm{~mol}$ propionate, and $12.4 \pm 0.6 \mathrm{~mol} / 100 \mathrm{~mol}$ butyrate. Concentrations of VFA and VFA composition did not differ between groups. Total VFA concentrations were affected $(P<0.05)$ by block.

\section{Glycogen and Fat Content and Gene Expression of Gluconeogenic Enzymes and GLUT2 in Liver}

Glycogen content did not differ with respect to diet but was affected by block $(P<0.05)$. Hepatic fat content tended to be higher $(P<0.1)$ in FD than in SD. Glycogen content correlated negatively with plasma BHBA $(\mathrm{r}=-0.63 ; P<0.01)$ and plasma NEFA $(\mathrm{r}=$ $-0.48 ; P<0.05)$. Hepatic fat content correlated positively with plasma BHBA $(\mathrm{r}=0.63 ; P<0.01)$, NEFA

Table 3. Plasma concentrations of metabolites in cows fed starch (SD) and rumen-protected fat (FD) diets for 4 wk between 98 and 124 DIM

\begin{tabular}{|c|c|c|c|c|c|c|}
\hline Variable $^{1}$ & \multicolumn{2}{|c|}{ Group } & $\mathrm{SE}$ & \multicolumn{3}{|c|}{ ANOVA ( $P$-value $)$} \\
\hline Triglycerides, $\mu \mathrm{mol} / \mathrm{L}$ & 99 & 122 & 4.6 & 0.001 & 0.05 & 0.3 \\
\hline $\mathrm{BHBA}, \mu \mathrm{mol} / \mathrm{L}$ & 857 & 795 & 49 & 0.4 & 0.05 & 0.6 \\
\hline Lactate, $\mu \mathrm{mol} / \mathrm{L}$ & 723 & 631 & 72 & 0.4 & 0.4 & 0.4 \\
\hline Urea, $\mathrm{mmol} / \mathrm{L}$ & 5.2 & 4.9 & 0.27 & 0.4 & 0.01 & 0.13 \\
\hline
\end{tabular}

${ }^{1}$ Values are LSM with pooled SE. 
Table 4. Plasma concentrations of glucose, insulin, and glucagon during glucose tolerance test (GTT) on d 26 of the study in cows fed starch (SD) and rumen-protected fat (FD) diets for 4 wk between 98 and 124 DIM

\begin{tabular}{|c|c|c|c|c|}
\hline \multirow[b]{2}{*}{ Variable $^{1}$} & \multicolumn{2}{|c|}{ Group } & \multirow[b]{2}{*}{$\mathrm{SE}$} & \multirow{2}{*}{$\begin{array}{l}\text { SD vs. FD } \\
(P \text {-value })\end{array}$} \\
\hline & $\mathrm{SD}$ & FD & & \\
\hline \multicolumn{5}{|c|}{ Fasting concentrations before GTT } \\
\hline Glucose, $\mathrm{mmol} / \mathrm{L}$ & 3.9 & 3.1 & 0.21 & 0.05 \\
\hline Insulin, $\mu \mathrm{g} / \mathrm{L}$ & 0.15 & 0.14 & 0.02 & 0.6 \\
\hline Glucagon, ng/L & 82 & 98 & 6.7 & 0.1 \\
\hline \multicolumn{5}{|l|}{ Area under the curve } \\
\hline Glucose, $\mathrm{mmol} / \mathrm{L}$ & 99.1 & 119 & 8.1 & 0.1 \\
\hline Insulin, $\mu \mathrm{g} / \mathrm{L}$ & 29.2 & 29.6 & 5.8 & 0.9 \\
\hline Glucagon, ng/L & 225 & 200 & 42.4 & 0.7 \\
\hline Glucose half-life, min & 32.4 & 27.5 & 5.1 & 0.5 \\
\hline
\end{tabular}

${ }^{1}$ Values are LSM with pooled SE.

A

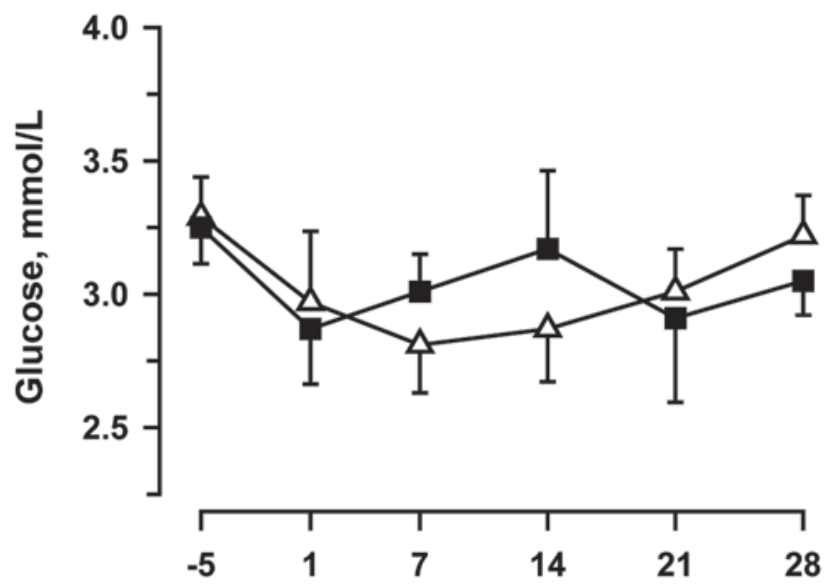

Time relative to RPF feeding, $d$

C

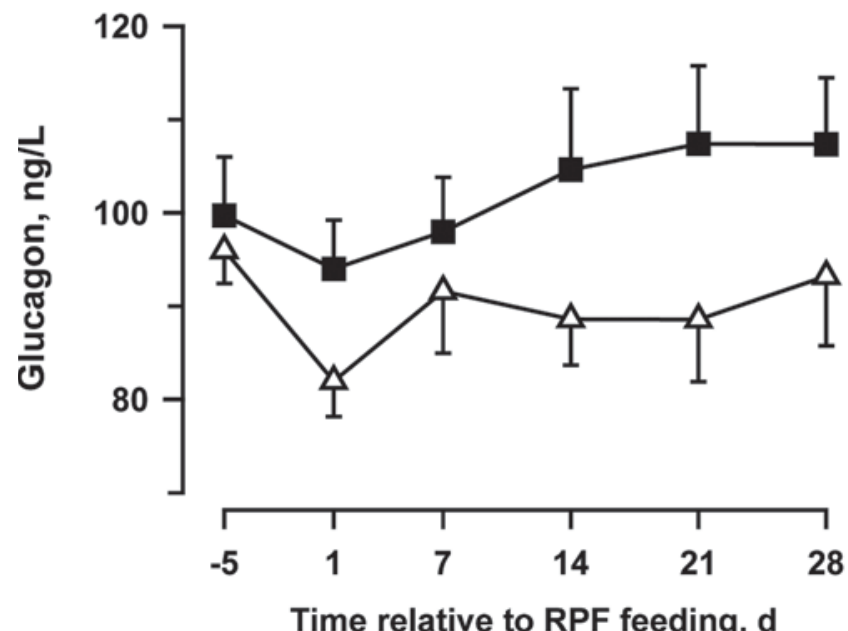

B

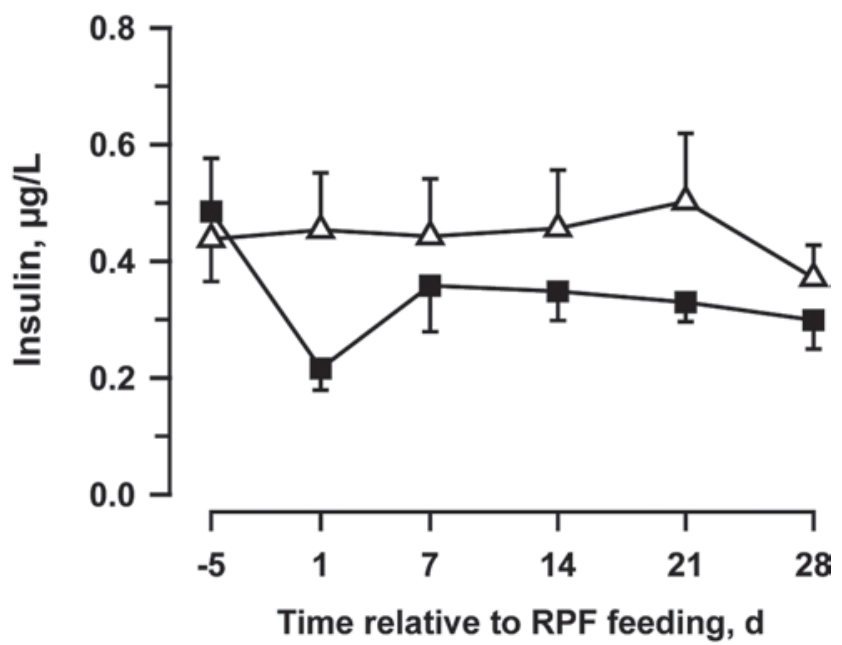

$\mathrm{D}$

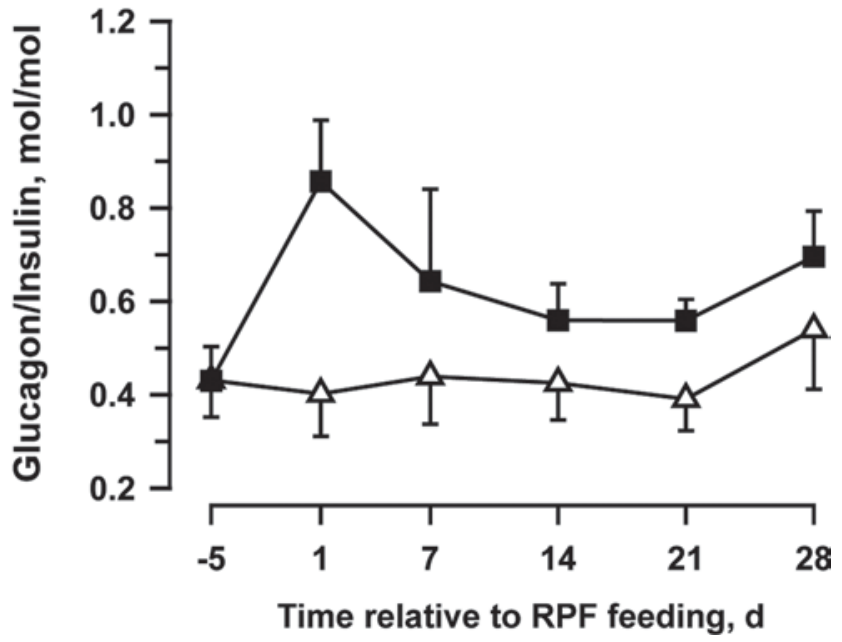

Figure 1. Plasma concentrations of glucose (A), insulin (B), glucagon (C), and glucagon to insulin ratio (D) in cows fed starch (SD; $\Delta$ ) and rumen-protected fat $(\mathrm{RPF}) \operatorname{diet}(\mathrm{FD} ; \mathbf{\square})$ for 4 wk between 98 and 124 DIM. 
( $\mathrm{r}=0.41 ; P<0.1)$, and the glucagon to insulin ratio $(\mathrm{r}=0.47 ; P<0.1)$.

Abundance of PC, PEPCK, and G6Pase mRNA in liver were related to $\beta$-actin, which was used as the housekeeping gene and which was not affected by dietary treatment. Levels of G6Pase mRNA were higher $(P<0.05)$ in $\mathrm{SD}$ than in FD. A linear regression was found between fasting plasma glucose concentration and hepatic G6Pase mRNA abundance: $\mathrm{y}=6.2 \mathrm{x}-$ $13.5\left(\mathrm{R}^{2}=0.52\right)$.

\section{DISCUSSION}

\section{Feed Intake and Milk Performance}

Several studies support the observation herein that DMI is reduced after RPF feeding, especially in mid lactation when cows are in a positive energy balance (Benson et al., 2001; Onetti and Grummer, 2004; Weiss and Pinos-Rodríguez, 2009). The reasons are presently under investigation and reduction of DMI may be related to changes in gastrointestinal hormones or hepatic fat oxidation (Allen et al., 2005; Relling and Reynolds, 2007). Because energy content was greater in $\mathrm{FD}$ than in $\mathrm{SD}$, energy intake, calculated as $\mathrm{NE}_{\mathrm{L}}$, did not differ between feeding groups. Differences in energy components of FD and SD diets, however, were as targeted, namely a higher starch intake in SD cows and a higher fat intake in FD cows. Previous studies indicated increased milk yield when RPF as Ca soap was fed (Onetti and Grummer, 2004; Voigt et al., 2005; Hammon et al., 2008). Surprisingly, this was not the case in our study. However, milk production was slightly higher in SD than in FD cows before start of the experimental feeding (Duske et al., 2009), but was at the same level in SD and FD cows during the experimental period, indicating a slight effect of fat feeding on milk production. In addition, milk protein decreased with time in FD cows. Lower milk protein content has often been seen in cows fed RPF because of insufficient microbial protein production in rumen after RPF feeding, resulting in a deficit of utilizable protein and less amino acid supply of the mammary gland (Chilliard, 1993; Onetti and Grummer, 2004). Although more rumen-protected protein was included in FD than in SD, this was obviously not enough to counteract the potentially decreased microbial protein, in contrast to previous studies (Voigt et al., 2005; Hammon et al., 2008). Furthermore, the lower levels of plasma insulin in FD cows may have led to decreased amino acid uptake and protein synthesis in the mammary gland (Mackle et al., 2000). Milk fat content was not affected by RPF feeding in our study; however, results on milk fat content after RPF feeding have been inconsistent and varied with regard to forage composition of the diet (Onetti and Grummer, 2004; Weiss and Pinos-Rodríguez, 2009). As expected, milk fatty acid composition responded to RPF feeding with more PUFA and less medium-chain fatty acids in the milk fat of FD compared with that of SD cows (Palmquist and Jenkins, 1980; Weiss and Pinos-Rodríguez, 2009).

\section{Metabolic Changes in Blood with Emphasis on Glucose Metabolism}

Whereas plasma concentrations of BHBA, lactate, urea, and bilirubin showed no diet effects, plasma triglyceride and NEFA concentrations were higher in FD than in SD cows (Table 3). These findings supports previous data on RPF feeding in dairy cows, using the same RPF source (Voigt et al., 2005; Hammon et al., 2008; Duske et al., 2009) or other RPF sources (Palmquist and Jenkins, 1980; Emery and Herdt, 1991; van Knegsel et al., 2005). Elevated plasma NEFA concentrations result from hydrolyzed triglycerides that escape tissue uptake (Grummer and Carroll, 1991; Chilliard, 1993). In addition, hepatic lipolytic activities are potentially enhanced during fat feeding (Chilliard, 1993). Impaired insulin action due to high fat intake may also support NEFA release from adipose tissues in dairy cows (Chilliard, 1993). However, the observed negative association between plasma concentrations of NEFA and insulin indicated that the antilipolytic effect of insulin on adipose tissue was not impaired and support earlier findings that RPF feeding did not affect insulin action in dairy cows (Blum et al., 1999). Lower plasma insulin concentrations in FD cows per se may have caused elevated plasma NEFA concentrations in these cows (Vernon, 2005a). Furthermore, we cannot rule out the possibility that reduced DMI led to elevated plasma NEFA concentrations in the FD cows.

Plasma glucose concentrations in weekly blood samples were not affected by RPF feeding, but fasting glucose concentrations before GTT were reduced in FD cows (Figure 1A; Table 4), when cows were $12 \mathrm{~h}$ without food, and gluconeogenic precursors from digested food such as propionate were less available for endogenous glucose production (Brockman, 2005). Reduced plasma glucose concentrations were observed in some (van Knegsel et al., 2005), but not all (Blum et al., 1999), studies after RPF feeding, and support our previous findings (Hammon et al., 2008; Duske et al., 2009). One explanation for the reduced fasting plasma glucose was probably the reduced DMI in FD cows that resulted in lower intake of gluconeogenic precursors, although energy intake did not differ between dietary treatments. Our study revealed no differences in glucose clearance rate with regard to diet, as indicated by comparable 
Table 5. Glycogen and fat content as well as mRNA levels of pyruvate carboxylase (PC), cytosolic phosphoenolpyruvate carboxykinase (PEPCK), glucose-6-phosphatase (G6Pase), and glucose transporter (GLUT2) in liver of cows fed starch (SD) and rumen-protected fat (FD) diets for 4 wk between 98 and 124 DIM

\begin{tabular}{|c|c|c|c|c|}
\hline \multirow[b]{2}{*}{ Variable $^{1}$} & \multicolumn{2}{|c|}{ Group } & \multirow[b]{2}{*}{$\mathrm{SE}$} & \multirow{2}{*}{$\begin{array}{l}\text { SD vs. FD } \\
(P \text {-value })\end{array}$} \\
\hline & SD & FD & & \\
\hline Glycogen content, $\mathrm{mg} / \mathrm{g}$ of DM & 36.3 & 33.3 & 4.6 & 0.6 \\
\hline $\begin{array}{l}\text { Fat content, } \mathrm{mg} / \mathrm{g} \text { of } \mathrm{DM} \\
\text { mRNA level relative to } \beta \text {-actin }\end{array}$ & 142 & 154 & 4.7 & 0.1 \\
\hline $\mathrm{PC}$ & 0.35 & 0.46 & 0.15 & 0.6 \\
\hline PEPCK & 2.77 & 1.68 & 0.89 & 0.4 \\
\hline G6Pase & 11.44 & 3.96 & 2.12 & 0.05 \\
\hline GLUT2 & 1.44 & 1.22 & 0.36 & 0.7 \\
\hline
\end{tabular}

${ }^{1}$ Values are LSM with pooled SE.

glucose half-life in plasma of SD and FD cows during GTT, but a trend for a greater glucose increase after glucose infusion in FD cows was observed (Table 4). Whether this was a consequence of less peripheral insulin response in FD cows due to fat feeding needs further investigation and cannot be concluded from the present study. However, peripheral insulin response in ruminants is affected by tissue fat content, for example, in muscle (Vernon, 2005a), and muscle fat might have been increased after fat feeding in FD cows. Plasma insulin and glucagon concentrations during the experimental period generated an elevated glucagon:insulin ratio in FD cows (Figure 1), suggesting differences in homeostatic glucose regulation after RPF feeding or a consequence of reduced DMI in FD cows. Lower plasma insulin concentrations were observed in most studies feeding RPF to dairy cows (van Knegsel et al., 2005), but not in all studies (Blum et al., 1999). Although insulin concentrations were lower in FD than in SD cows, insulin secretion after glucose challenge during GTT did not differ between groups (Table 4). Therefore, the pancreatic insulin response due to glucose challenge was not impaired after RPF feeding. In general, insulin secretion after glucose challenge can be affected by dietary RPF and depends on fatty acid composition in the RPF diet (Pires et al., 2008), but insulin secretion in RPF-fed cows during hyperglycemic clamp studies did not differ from insulin secretion in cows fed a diet enriched with starch (Blum et al., 1999).

Elevated plasma glucagon and glucagon:insulin ratio in FD cows (Figure 1) support previous findings (Hammon et al., 2008) and might be related to reduced DMI in FD cows. The literature indicates that an elevated glucagon:insulin ratio leads to an increase of plasma glucose concentrations when considering glucagon and insulin action on glucose metabolism in cattle (Danfaer, 1994; Donkin, 1999; Drackley et al., 2001). We have found a positive relation of glucose and insulin concentrations during fasting, but neither glucagon nor the glucagon:insulin ratio was related to plasma glucose concentrations in our study. However, this may indicate that glucose homeostasis was operating as expected; namely, keeping plasma glucose constant as shown in Figure 1A.

\section{Diet Effects on Hepatic Fat Content and Glucose Metabolism}

Cows that received the FD diet showed slightly elevated fat content in liver (Table 5), which probably resulted from a higher hepatic NEFA uptake in FD cows. Plasma NEFA concentrations are directly related to hepatic NEFA uptake in cows (Drackley et al., 2001; Vernon, 2005b), and the elevated fat content in FD cows probably reflected an increased triglyceride storage after re-esterification of NEFA in the liver (Drackley and Andersen, 2006).

Reduced plasma glucose concentrations in the fasted state in FD cows were probably a consequence of decreased hepatic G6Pase gene expression in FD cows. Hepatic G6Pase mRNA content was highly related to fasting plasma glucose concentrations but was not related to the glucagon:insulin ratio in plasma, which was expected to regulate G6Pase gene expression (van Schaftingen and Gerin, 2002). Decreased fasting plasma glucose concentrations and lower hepatic G6Pase mRNA concentrations in FD cows could have been caused by reduced DMI and, therefore, intake of gluconeogenic substances such as propionate. However, measurements of propionate in rumen fluid revealed no differences between groups, a result supported by previous findings (Hammon et al., 2008).

Hepatic gluconeogenesis can be depressed due to elevated fat content in liver, and the depression depends on fatty acid composition (Cadórniga-Valiño et al., 1997; Mashek and Grummer, 2003). Studies using dairy cows with induced fatty liver during the periparturient period pointed at impaired hepatic gluconeogenic 
capacity (Rukkwamsuk et al., 1999; Murondoti et al., 2004). Reduced hepatic G6Pase mRNA content in FD cows might support these findings, because G6Pase is important for glucose release into the blood, and hepatic fat content was higher in FD than in SD cows. However, we found no differences in hepatic gene expression of PC, PEPCK, or GLUT2 (Table 5). Studies on gene expression of gluconeogenic enzymes revealed distinct regulation of individual enzymes with regard to the physiological state in calves (Hammon et al., 2003, 2005) and dairy cows (Greenfield et al., 2000; Cedeño et al., 2008). Cows that showed high liver fat content but did not develop fatty liver syndrome during the periparturient period revealed elevated hepatic PC and G6Pase mRNA concentrations (Hammon et al., 2009), indicating that high hepatic fat content per se may not compromise gene expression of gluconeogenic enzymes in liver. Moreover, previous results using a comparable feeding model as in this study indicated no differences in whole-body glucose production, although we have found lower plasma glucose concentrations in FD cows (Hammon et al., 2008). However, reduced hepatic glucose output was found in dairy cows after oral infusion of vegetable oil containing much more PUFA than the fat used in our studies (Benson et al., 2002). Therefore, the influence of RPF feeding or elevated hepatic fat content on gluconeogenic activity and glucose output in liver of dairy cows is conflicting and needs further clarification. Because we have not pair-fed SD cows to achieve same level of DMI as in FD cows, a direct RPF feeding effect on gluconeogenic activity could not be verified in our study.

In conclusion, RPF feeding in dairy cows during mid-lactation affects glucose metabolism and hepatic gene expression related to gluconeogenic activity. Furthermore, hepatic G6Pase gene expression might be involved in the regulation of glucose homeostasis in dairy cows. Reduced fasting glucose concentrations in plasma of FD cows might be a consequence of less DMI providing less gluconeogenic precursors. Changes in plasma glucose and hepatic gluconeogenic gene expression were not related to changes in the glucagon:insulin ratio in plasma, and glucose-induced insulin secretion was not impaired during RPF feeding. Because glucose clearance is not affected during RPF feeding, regulation of plasma glucose concentrations might be related to the reduced hepatic glucose output, but further investigations are needed to clarify the role of gluconeogenic precursor intake on plasma glucose regulation.

\section{ACKNOWLEDGMENTS}

The authors gratefully acknowledge the laboratory staff (Claudia Reiko, Helga Schott, Brigitte Waischnow) and animal care takers (Dirk Oswald) of the Research Unit Nutritional Physiology (Dummerstorf, Germany) as well as Gunter Klautschek and the Animal Experimental Unit of the FBN (Dummerstorf, Germany) for excellent technical assistance. Hajenol was a gift of Harles und Jentzsch (Uetersen, Germany). Protected soybean meal was generously provided by Wulfamast (Dinklage-Wulfenau, Germany). The study was supported by a grant of the Deutsche Forschungsgemeinschaft (Bonn, Germany) to H.M.S. and C.C.M. (SE 326/13-2), and the core budget of the FBN.

\section{REFERENCES}

Allen, M. S., B. J. Bradford, and K. J. Harvatine. 2005. The cow as a model to study food intake regulation. Annu. Rev. Nutr. 25:523-547.

Bauman, D. E. 2000. Regulation of nutrient partitioning during lactation: homeostasis and homeorhesis revisited. Pages 311-328 in Ruminant Physiology: Digestion, Metabolism, Growth and Reproduction. P. B. Cronje, ed. CAB International, Wallingford, UK.

Benson, J. A., C. K. Reynolds, P. C. Aikman, B. Lupoli, and D. E. Beever. 2002. Effects of abomasal vegetable oil infusion on splanchnic nutrient metabolism in lactating dairy cows. J. Dairy Sci. 85:1804-1814.

Benson, J. A., C. K. Reynolds, D. J. Humphries, S. M. Rutter, and D. E. Beever. 2001. Effect of abomasal infusion of long-chain fatty acids on intake, feeding behavior and milk production in dairy cows. J. Dairy Sci. 84:1182-1191.

Blum, J. W., R. M. Bruckmaier, and P. Y. Vacher. 1999. Insulindependent whole-body glucose utilization and insulin-responses to glucose in week 9 and week 19 of lactation in dairy cows fed rumen-protected crystalline fat or free fatty acids. Domest. Anim. Endocrinol. 16:123-134.

Brockman, R. P. 2005. Glucose and short-chain fatty acid metabolism. Pages 291-310 in Quantitative Aspects of Ruminant Digestion and Metabolism. J. Dijkstra, J. M. Forbes, and J France, ed. CAB International, Wallingford, UK.

Cadórniga-Valiño, C., R. R. Grummer, L. E. Armentano, S. S. Donkin, and S. J. Bertics. 1997. Effects of fatty acids and hormones on fatty acid metabolism and gluconeogenesis in bovine hepatocytes. J. Dairy Sci. 80:646-656.

Cedeño, E. M., S. L. Koser, and S. S. Donkin. 2008. Quantification of glucose-6-phosphatase mRNA abundance in liver of transition dairy cows. J. Dairy Sci. 91(Suppl. 1):424. (Abstr.)

Chilliard, Y. 1993. Dietary fat and adipose tissue metabolism in ruminants, pigs, and rodents: a review. J. Dairy Sci. 76:3897-3931.

Danfaer, A. 1994. Nutrient metabolism and utilization in the liver. Livest. Prod. Sci. 39:115-127.

Donkin, S. S. 1999. Role of the endocrine pancreas in animal metabolism, growth and performance. Pages 315-328 in Biology of the Pancreas in Growing Animals. S. G. Pierynowski and R. Zabielski, ed. Elsevier, Amsterdam, the Netherlands.

Drackley, J. K., and J. B. Andersen. 2006. Splanchnic metabolism of long-chain fatty acids in ruminants. Pages 199-224 in Ruminant Physiology: Digestion, Metabolism and Impact of Nutrition on Gene Expression, Immunology and Stress. K. Sejrsen, T. Hvelplund, and M. O. Nielsen, ed. Wageningen Academic Publishers, Wageningen, the Netherlands.

Drackley, J. K., T. R. Overton, and G. N. Douglas. 2001. Adaptations of glucose and long-chain fatty acid metabolism in liver of dairy cows during the periparturient period. J. Dairy Sci. 84(E Suppl.):100-112.

Duske, K., H. M. Hammon, A. K. Langhof, O. Bellmann, B. Losand, K. Nürnberg, G. Nürnberg, H. Sauerwein, H. M. Seyfert, and C. C. Metges. 2009. Metabolism and lactation performance in dairy cows fed a diet containing rumen-protected fat during the last twelve weeks of gestation. J. Dairy Sci. 92:1670-1684. 
Emery, R. S., and T. H. Herdt. 1991. Lipid nutrition. Vet. Clin. North Am. Food Anim. Pract. 7:341-352.

German Society of Nutrition Physiology. 2001. Ausschuss für Bedarfsnormen der Gesellschaft für Ernährungsphysiologie,. No. 8. Empfehlungen zur Energie- und Nährstoffversorgung der Milchkühe und Aufzuchtrinder (Recommended energy and nutrient supply for dairy cows and growing cattle). DLG-Verlag Frankfurt a. Main, Germany.

Greenfield, R. B., M. J. Cecava, and S. S. Donkin. 2000. Changes in mRNA expression for gluconeogenic enzymes in liver of dairy cattle during the transition to lactation. J. Dairy Sci. 83:1228-1236.

Grummer, R. R., and D. J. Carroll. 1991. Effects of dietary fat on metabolic disorders and reproductive performance of dairy cattle. J. Anim. Sci. 69:3838-3852.

Hammon, H. M., O. Bellmann, J. Voigt, F. Schneider, and C. Kühn. 2007. Glucose-dependent insulin response and milk production in heifers within a segregating resource family population. J. Dairy Sci. 90:3247-3254.

Hammon, H. M., and J. W. Blum. 1998. Metabolic and endocrine traits of neonatal calves are influenced by feeding colostrum for different duration or only milk replacer. J. Nutr. 128:624-632.

Hammon, H. M., C. C. Metges, P. Junghans, F. Becker, O. Bellmann, F. Schneider, G. Nürnberg, P. Dubreuil, and H. Lapierre. 2008. Metabolic changes and net portal flux in dairy cows fed a ration containing rumen-protected fat as compared to a control diet. J. Dairy Sci. 91:208-217.

Hammon, H. M., C. Philipona, Y. Zbinden, J. W. Blum, and S. S. Donkin. 2005. Effects of dexamethasone and growth hormone treatment on hepatic gluconeogenic enzymes in calves. J. Dairy Sci. 88:2107-2116

Hammon, H. M., S. N. Sauter, M. Reist, Y. Zbinden, C. Philipona, C. Morel, and J. W. Blum. 2003. Dexamethasone and colostrum feeding differently affect hepatic gluconeogenic enzymes in neonatal calves. J. Anim. Sci. 81:3095-3106.

Hammon, H. M., G. Stürmer, F. Schneider, A. Tuchscherer, H. Blum, T. Engelhard, A. Genzel, R. Staufenbiel, and W. Kanitz. 2009. Performance and metabolic and endocrine changes with emphasis on glucose metabolism in high-yielding dairy cows with high and low fat content in liver after calving. J. Dairy Sci. 92:1554-1566.

Linzell, J. L. 1972. Mechanism of secretion of the aqueous phase of milk. J. Dairy Sci. 55:1316-1322.

Littell, R. C., P. R. Henry, and C. B. Ammerman. 1998. Statistical analysis of repeated measures data using SAS procedures. J. Anim. Sci. 76:1216-1231.

Mackle, T. R., D. A. Dwyer, K. L. Ingvartsen, P. Y. Chouinard, D. A Ross, and D. E. Bauman. 2000. Effects of insulin and postruminal supply of protein on use of amino acids by the mammary gland for milk protein synthesis. J. Dairy Sci. 83:93-105.

Mashek, D. G., and R. R. Grummer. 2003. Effects of long chain fatty acids on lipid and glucose metabolism in monolayer cultures of bovine hepatocytes. J. Dairy Sci. 86:2390-2396.

Murondoti, A., R. Jorritsma, A. C. Beynen, T. Wensing, and M. J. H. Geelen. 2004. Activities of the enzymes of hepatic gluconeogenesis in periparturient dairy cows with induced fatty liver. J. Dairy Res. 71:129-134.

Naumann, C., and R. Bassler. 1993. Die chemische Untersuchung von Futtermitteln. VDLUFA-Verlag, Darmstadt, Germany.
Onetti, S. G., and R. R. Grummer. 2004. Response of lactating cows to three supplemental fat sources as affected by forage in the diet and stage of lactation: a meta-analysis of literature. Anim. Feed Sci. Technol. 115:65-82.

Palmquist, D. L., and T. C. Jenkins. 1980. Fat in lactation rations: Review. J. Dairy Sci. 63:1-14.

Pfaffl, M. W. 2001. A new mathematical model for relative quantification in real-time RT-PCR. Nucleic Acids Res. 29:2002-2007.

Pires, J. A. A., J. B. Pescara, A. E. Brickner, N. Silva del Rio, A. P. Cunha, and R. R. Grummer. 2008. Effects of abomasal infusion of linseed oil on responses to glucose and insulin in Holstein cows. J. Dairy Sci. 91:1378-1390.

Reist, M., D. Erdin, D. von Euw, K. Tschuemperlin, H. Leuenberger, C. Delavaud, Y. Chilliard, H. M. Hammon, N. Kuenzi, and J. W. Blum. 2003. Concentrate feeding strategy in lactating dairy cows: metabolic and endocrine changes with emphasis on leptin. J. Dairy Sci. 86:1690-1706.

Relling, A. E., and C. K. Reynolds. 2007. Feeding rumen-inert fats differing in their degree of saturation decreases intake and increasees plasma concentrations of gut peptides in lactating dairy cows. J. Dairy Sci. 90:1506-1515.

Rukkwamsuk, T., T. Wensing, and M. J. Geelen. 1999. Effect of fatty liver on hepatic gluconeogenesis in periparturient dairy cows. J. Dairy Sci. 82:500-505.

SAS Institute Inc. 2004. SAS/STAT 9.1 User's Guide. SAS Institute Inc., Cary, NC.

Shen, Z. M., H. M. Seyfert, B. Löhrke, F. Schneider, R. Žitnan, A. Chudy, S. Kuhla, H. M. Hammon, J. W. Blum, H. Martens, H. Hagemeister, and J. Voigt. 2004. Energy rich diet causes rumen papillae proliferation associated with increased IGF-1 levels and IGF type 1 receptors in young goats. J. Nutr. 134:11-17.

van Knegsel, A. T., H. van den Brand, J. Dijkstra, S. Tamminga, and B. Kemp. 2005. Effect of dietary energy source on energy balance, production, metabolic disorders and reproduction in lactating dairy cows. Reprod. Nutr. Dev. 45:665-688.

van Schaftingen, E., and I. Gerin. 2002. The glucose-6-phosphatase system. Biochem. J. 362:513-532.

Vernon, R. G. 2005a. Metabolic regulation. Pages 443-468 in Quantitative Aspects of Ruminant Digestion and Metabolism. J. Dijkstra, J. M. Forbes, and J. France, ed. CAB International, Wallingford, UK.

Vernon, R. G. 2005b. Lipid metabolism during lactation: A review of adipose tissue-liver interactions and the development of fatty liver. J. Dairy Res. 72:460-469.

Voigt, J., K. Gaafar, W. Kanitz, D. Precht, F. Becker, F. Schneider, M. Spitschak, U. Schönhusen, P. Junghans, J. R. Aschenbach, and G. Gäbel. 2005. Verwertung von Glucose und langkettigen Fettsäuren durch die laktierende Milchkuh bei Fütterung einer fettangereicherten Diät. Dtsch. Tierarztl. Wochenschr. 112:423-425.

Voigt, J., S. Kuhla, K. Gaafar, M. Derno, and H. Hagemeister. 2006. Digestibility of rumen protected fat in cattle. Slovak J. Anim. Sci. 39:16-19.

Weiss, W. P., and J. M. Pinos-Rodríguez. 2009. Production responses of dairy cows when fed supplemental fat in low- and high-forage diets. J. Dairy Sci. 92:6144-6155. 